\title{
GERAGOGIKA RESOCJALIZACYJNA W JEDNOSTKACH PENITENCJARNYCH. STAROŚĆ, DŁUGOWIECZNOŚĆ WIĘZIENNA
}

\begin{abstract}
Toroń-Fórmanek Barbara, Geragogika resocjalizacyjna w jednostkach penitencjarnych. Starość, długowieczność więzienna [Social Rehabilitation Geragogy in Penitentiary Institutions. Prison Old-age and Longevity]. Studia Edukacyjne nr 50, 2018, Poznań 2018, pp. 257-273. Adam Mickiewicz University Press. ISSN 1233-6688. DOI: 10.14746/se.2018.50.17
\end{abstract}

For a human being deprived of freedom, prison isolation can be a source of frustration. However, the needs of the elderly due to specific conditioning connected with the aging process make their adaptation to prison conditions more complicated. The article concerns specific problems of seniors in custody in penitentiary units with reference to theoretical and practical aspects of pedagogy of senescence and resocialization geragogy. The main subject of interest of pedagogy of senescence is upbringing of an elderly person, understood as supporting their development (physical, mental, social, cultural, spiritual). Resocialization geragogy draws attention to the need to allow for psychophysical conditions of seniors, reinforcing their sense of dignity and relevance of subjecting them to supportive influence aiming at growing their awareness that senility is a good time to acquire knowledge, skills and create habits, attitudes and behaviors.

Key words: prisonization, prison isolation, resocialization geragogy, longevity resocialization of aging and old people, old age

\section{Zagadnienie starości w psychologii i pedagogice}

Psychologia traktuje starość jako ostatni etap rozwoju ontogenetycznego człowieka, który poprzedzają takie okresy, jak: dzieciństwo, młodość i wiek dojrzały ${ }^{1}$. Inne definicje tłumaczą ją jako

${ }^{1}$ H. Olszewski, Starość i starzenie się [w:] Encyklopedia psychologii, red. W. Szewczuk, Warszawa 1998, s. 855. 
końcowy etap procesu starzenia się, w którym procesy biologiczne, psychiczne i społeczne zaczynają oddziaływać względem siebie synergetycznie, prowadząc do naruszenia równowagi biologicznej i psychicznej człowieka, bez możliwości przeciwdziałania temu ${ }^{2}$.

O. Czerniawska z kolei zwraca uwagę na jej statyczny charakter oraz że jest ona zjawiskiem zarówno jednostkowym (starzeje się konkretny człowiek, który doświadcza uroków i wad tej fazy życia), jak i społecznym (starzeje się bowiem konkretna społeczność lokalna, wieś, miasto, osiedle, mieszkańcy domu, kraju, kontynentu, świata) ${ }^{3}$. Według Światowej Organizacji Zdrowia (WHO), starość przypada między 60. a 74. rokiem życia, późna starość - między 75. a 89., a długowieczność - od 90. roku życia ${ }^{4}$.

W odniesieniu do starości należy posługiwać się pojęciem geragogika. Słowo to pojawiło się w pedagogice niemieckiej w latach 50. XX wieku. Po raz pierwszy użył go w 1956 roku niemiecki gerontolog H. Mieskes. Aby ustalić etymologię wyrazu geragogika, należy sięgnąć do języka greckiego, w któ-

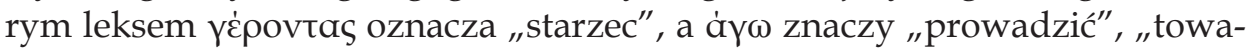
rzyszyć", „prowadzić do celu”, „wychowywać”.

Geragogika to nauka pedagogiczna, w centrum zainteresowań której mieszczą się pedagogiczne aspekty związane ze starością jako specyficznym etapem ludzkiego życia oraz ze starzeniem się jako naturalnym procesem, któremu podlegają wszystkie istoty ludzkie. Podmiotem zainteresowania geragogiki jest człowiek starszy, postrzegany z perspektywy szeroko rozumianej edukacji, trwającej przez całe życie. Ponadto jest nim również ogół społeczeństwa, z uwagi na akcentowany w geragogice postulat wychowania do starości, w starości i przez starość ${ }^{5}$.

Takie rozumienie pedagogiki starości znacznie wykracza poza takie pojęcia, jak gerontologia edukacyjna (określana jako uczenie się w późniejszych latach życia) i edukacja gerontologiczna (tj. nauczanie gerontologii, edukowanie do starości).

Od czasu pojawienia się tego terminu w Niemczech, na temat geragogiki powstało nie tylko wiele prac stanowiących efekt pracy znanych i cenionych na całym świecie autorów, ale zrodziły się także inne terminy, które miały być synonimami obco brzmiącej geragogiki. Były to: „gerontologia wychowaw-

\footnotetext{
2 A. Zych, Stownik gerontologii społecznej, Warszawa 2001, s. 202.

${ }^{3}$ O. Czerniawska, Starość wczoraj, dziś i jutro, [w:] Ludzie starsi w trzecim tysiącleciu. Szanse nadzieje - potrzeby, red. W. Wnuk, Wrocław 2002, s. 11.

${ }^{4}$ A. Nowicka, Starość jako faza życia człowieka, [w:] Wybrane problemy osób starszych, red. A. Nowicka, Kraków 2008, s. 18.

${ }^{5}$ A. Leszczyńska-Rejchert, Człowiek starszy $i$ jego wspomaganie - w strone pedagogiki starości, Olsztyn 2010; taże, Geragogika jako subdyscyplina pedagogiczna - założenia i formy realizacji, [w:] Edukacja wobec starości - tradycja i wspótczesność, red. A. Stopińska-Pająk, Chowanna, 2009, 52(65), 2014, 2(33), s. 226.
} 
cza” (Erziehungsgeontologie), czy „pedagogika podeszłego wieku” (Pädagogik des Alterns). W języku angielskim znajdziemy takie odpowiedniki, jak: geragogy i educational gerontology.

W literaturze polskiej nazwa geragogika ugruntowała się i według Adama Zycha, Anny Leszczyńskiej-Rejchert (2009) oraz Elżbiety Dubas (2005) jest działem pedagogiki, według Jolanty Leśniak - działem andragogiki, a według W. Bachmanna i Jerzego Strochmiałka - działem pedagogiki specjalnej ${ }^{6}$. $\mathrm{W}$ dwóch pierwszych przypadkach zasadniczą kwestię stanowi przedmiot badania lub obszar badawczy, którym jest starzenie się i starość. Natomiast, fakt, iż geragogika jest subdyscypliną $\mathrm{w}$ jednym wypadku pedagogiczną, a w drugim andragogiczną, wskazuje na to, że stosuje się w niej te same metody badawcze co w pedagogice i andragogice. Inaczej jest, kiedy umieścimy geragogikę w obszarze pedagogiki specjalnej, która interesuje się ludźmi, czy też grupami osób charakteryzującymi się różnego rodzaju deficytami, jednak należy pamiętać, że w odniesieniu do starości deficyty te nie są wrodzone, ani nie wynikają z wydarzeń losowych, tylko stanowią niejako naturalny rezultat biegu życia ${ }^{7}$.

Obecnie pedagogikę starości definiuje się jako wszechstronną naukę o wychowaniu człowieka od jego narodzin aż po śmieć, z kolei pedagogizacja stanowi proces kształtowania i wychowania, nauczania i poszerzania wiedzy przez całe życie człowieka. Tym samym, geragogika wpisuje się we współczesne, nowoczesne pojmowanie pedagogiki ${ }^{8}$.

Geragogika zdobyła rangę w naukach pedagogicznych, kiedy zrozumiano, że kształcenie i wychowanie człowieka nie stanowi proces skończony, bowiem możliwe jest przez całe jego życie, a człowiek stary zasługuje na uwagę i troskę o jego byt psychofizyczny. Jest stosunkowo młodą dyscypliną, choć jej zalążki odnajdujemy już w pracach Jana Amosa Komeńskiego (1592-1670), a w jednej z nich pisał:

Bo starość porównuje się do zimy. A zima jest sama przez się jałowa, nie przynosi żadnych owoców, pozwala tylko ludziom korzystać z tego, co zebrali; kto nie zebrał niczego w lecie i w jesieni, będzie cierpiał niedostatek, będzie głodował (...) Jeśli więc nie życzysz sobie starości jałowej, ciężkiej, głodnej, tedy dopóki okres twego wieku i siły na to pozwalają, napełnij spiżarnie swoje, swoje spichlerze i komory pożywieniem mądrości i innymi nieodzownymi dla życia zapasami silnego zdrowia itp. Wtedy dopiero będziesz mógł się spodziewać, że starość (jeśli przyjdzie) nie będzie dla ciebie smutna, lecz rozkoszna, nie uciążliwa, lecz triumfująca (... $)^{9}$.

\footnotetext{
6 A. Tokaj, U progu starości (studium socjopedagogiczne), Poznań 2000.

7 J. Halicki, Edukacja osób starszych w Polsce - jej wymiar teoretyczny i praktyczny. Studia nad kondycją edukacji dorostych, Edukacja Dorosłych 2013, 2, s. 10.

8 M. Uglorz, Geragogika, http://mku.blox.pl/resource/Geragogika.pdf

9 J.A. Komeński, Pampaedia, Wrocław 1973, s. 248.
} 
Główny przedmiot zainteresowań pedagogiki starości stanowi wychowanie człowieka starszego, rozumiane jako wspomaganie jego rozwoju (fizycznego, umysłowego, społecznego, kulturalnego, duchowego), z tym że owo wspomaganie rozwoju oznacza tu niedyrektywne kierowanie rozwojem, w którym wychowawca pełni głównie funkcję animatora, doradcy, mediatora lub organizatora, zachowując podmiotowy charakter relacji10.

\section{Adaptacja do warunków więziennych seniorów}

Izolacja więzienna jest to „odłączenie od społeczeństwa w celu wykonania kary za popełnione przestępstwa"11. Stanowi sytuację trudną, będącą efektem decyzji podjętej przez inne osoby, czyli ma charakter przymusu zewnętrznego. Skazany, wchodzący w środowisko więzienne, jest najczęściej człowiekiem ukształtowanym, posiadającym określone cechy osobowościowe, doświadczenie życiowe oraz pamięć powiązań z otoczeniem, do jakiego przynależał, a te czynniki mogą sprzyjać bądź utrudniać więzienną adaptację ${ }^{12}$.

Przystosowanie (adaptacja) oznacza zdolność dopasowania się człowieka do zmieniających się warunków fizycznych i społecznych oraz umiejętność osiągnięcia w nich ważnych dla siebie celów ${ }^{13}$.

Izolacja więzienna człowieka starego niesie ze sobą ryzyko pojawienia się lub nasilenia cech zniedołężnienia bądź procesów dezintegracyjnych zachodzących w organizmie seniora. Hans Thomae ${ }^{14}$ podkreśla, że starość nie jest wyłącznie efektem przeżytych lat życia, ale głównie ukształtowanym obrazem siebie, połączonym ze stanem zdrowia, cechami osobowości i aktywnością życiową. Istotny jest aspekt subiektywnego i obiektywnego odczucia starości. W literaturze spotyka się stanowisko, że osobowość ludzi w wieku podeszłym nie zmienia się z powodu starości. Z drugiej strony wiadomo, że apatia, obojętność, brak zainteresowania jako czynniki zewnętrzne mogą wpływać na człowieka, zmieniając jego sposób interpretowania rzeczywi-

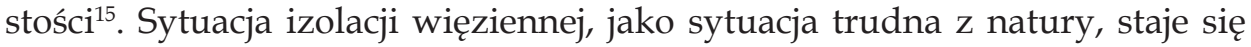
źródłem frustracji. Dotychczasowe postrzeganie własnej sytuacji życiowej

\footnotetext{
${ }^{10}$ A. Leszczyńska-Rejchert, Geragogika jako subdyscyplina pedagogiczna, s. 227.

${ }_{11}$ A. Orzechowska (red.), Samouszkodzenia wśród więźniów a czynniki psychospoteczne, [w:] Suicydologia, t. 4, nr 1, Warszawa 2008, s. 47.

12 Por. M. Ciosek, Psychologia sadowa i penitencjarna, wyd. II, Warszawa 2003, s. 211.

13 Tamże, s. 211

${ }_{14}$ Za: A. Leszczyńska-Rejchert, Człowiek starszy i jego wspomaganie - w strone pedagogiki starości, Olsztyn 2010, s. 48.

15 A. Kowalczyk, Specyfika problemów osób starszych w zakładzie karnym, [w:] Senior w obliczu izolacji penitencjarnej. Konteksty teoretyczne, red. A. Jaworska, Bydgoszcz 2013, s. 160.
} 
u człowieka starego ulega zmianie, ale jest to zmiana na gorsze. Nasilają się lęki, myślenie staje się bardziej negatywne. Już sama świadomość końca życia budzi bowiem u jednostki poczucie zagrożenia.

Na starość zagrożone mogą zostać wartości, które mają istotne znaczenie dla istnienia jednostki, nie tylko życie fizyczne, ale sama wartość psychiczna. Oprócz wymienionych występują również lęki irracjonalne, lęki moralne z uwagi na zdawanie sobie sprawy ze zrealizowanych zadań i decyzji podejmowanych w ciągu życia. Do powyższych problemów dochodzi zmniejszone poczucie bezpieczeństwa związane z obniżeniem standardu życia, dołącza się izolacja społeczna związana z utratą pracy, zmniejszaniem się grona znajomych ${ }^{16}$.

Przymusowy pobyt w zakładzie karnym może być źródłem frustracji. Niezaspokojone potrzeby biologiczne i psychiczne wywołują zjawisko deprywacji ${ }^{17}$. Pozbawienie wolności wzbudza u skazanego poczucie skrzywdzenia oraz negatywne emocje typu: lęk, smutek, rozpacz, poczucie bezradności, gniew, nienawiść. Uczucia te powodują sytuacje konfliktowe, niekorzystnie wpływające na kondycję psychofizyczną osadzonych. Skumulowanie tych emocji często znajduje ujście (rozładowanie) poprzez agresję i autoagresję ${ }^{18}$. Dlatego, zdaniem M. Cioska ${ }^{19}$, do środowiska więziennego lepiej przystosowani są przestępcy wielokrotni, o bogatszym doświadczeniu i wyuczonych już mechanizmach adaptacyjnych, choć i oni przechodzą tak zwany ochronny lub regresywny typ przystosowania, polegający na obniżeniu poziomu aspiracji w sytuacji zwiększonych ograniczeń środowiska oraz pogodzeniu się z istniejącymi warunkami życia.

Uwięzienie pozbawia dopływu bodźców sensorycznych, możliwości zindywidualizowanego zaspokajania potrzeb, informacji.

Kara pozbawienia wolności wiąże się z odizolowaniem jednostki od środowiska wolnościowego, otoczenia, społeczeństwa i bliskich, a zatem zwiększa się prawdopodobieństwo doświadczania samotności ${ }^{20}$. Stanu samotności doświadcza oczywiście każdy człowiek na różnych etapach swojego życia, jednak okres starości jest pod tym względem szczególny. Postrzegamy bowiem ludzi starych głównie jako samotnych. Nie pracują już, a zatem ich kontakty z ludźmi są znacznie ograniczone, ich dzieci wyszły z domu i założyły swoje rodziny, a więc kontakty z nimi są rzadsze, często

\footnotetext{
16 Tamże.

17 Por. B. Waligóra, Deprywacja potrzeb u osób pozbawionych wolności, [w:] Problemy wspótczesnej penitencjarystyki w Polsce, t. 1, red. B. Hołyst, Warszawa 1984, s. 56.

${ }_{18}$ J. Nawój, Świat przemocy w więzieniu, [w:] Przemoc w więzieniu, red. J. Nawój, Kule 1998, s. 34-36.

19 Por. M. Ciosek, Psychologia sądowa, s. 211.

20 S. Grzesiak, Egzystencjalny wymiar starości w zakładzie karnym - doświadczanie czasu i samotności przez więźniów seniorów, [w:] Senior w obliczu izolacji, s. 99.
} 
doświadczają utraty współmałżonka, a do tego dochodzą jeszcze problemy zdrowotne. Wszystko to sprawia, że ludzie starsi czują się zepchnięci na margines. W sytuacji izolacji więziennej skazani seniorzy oprócz doświadczeń związanych z samym uwięzieniem, a więc ograniczeniem ich aktywności i wolności, mają również te związane $\mathrm{z}$ dyskryminacją $\mathrm{z}$ uwagi na ich wiek. I chociaż „bierność najczęściej dotyczy ludzi starych, gdyż ich aktywność jest ograniczona przez warunki zdrowotne, finansowe, izolację społeczną" ${ }^{21}$, to w zakładzie karnym jest ona bardziej skutkiem braku dostosowanych do ich potrzeb, możliwości i zainteresowań oferty zajęciowej niż wspomnianych przyczyn natury zdrowotnej i sprawności fizycznej. Seniorzy są zatem "skazani” na bierność, która staje się często powodem rozgoryczenia i potęguje osamotnienie ${ }^{22}$. Nie bez znaczenia dla bierności pozostaje kwestia czasu. Inaczej bowiem odczuwany jest on na wolności, inaczej $\mathrm{w}$ sytuacji uwięzienia. $\mathrm{W}$ izolacji więziennej czas niejako zwalnia, nabiera zupełnie nowego znaczenia. Świadomość upływającego czasu w przypadku skazanych seniorów ściśle wiąże się z perspektywą dożywocia i śmierci, wywołującą lęk, obawy niepowrotu na wolność oraz poczucie krzywdy, rozpaczy i osamotnienia ${ }^{23}$. Kara pozbawienia wolności u schyłku życia jest dla nich znacznie bardziej dotkliwa niż dla młodszych skazanych. Z jednej strony sprzyjać może refleksji nad własnym życiem, ale z drugiej uniemożliwia snucie planów.

Adaptacja do warunków totalnych - zdaniem E. Goffmana ${ }^{24}$ - może przybrać różne formy:

a) wycofania się z sytuacji - typ przystosowania polegający na odcięciu się od otoczenia i koncentracji na sobie, zobojętnienia na sprawy innych. Strategia ta może prowadzić do ucieczki w marzenia i idealizację, do egocentryzmu, więziennego infantylizmu, a nawet ostrej depersonalizacji i autyzmu;

b) taktyki buntu - przyjmującej postać bezkompromisowej, jawnej postawy oporu i wrogości wobec personelu (typowej zwłaszcza dla pierwszej fazy uwięzienia) lub postać utajnionej niechęci znajdującej wyraz w uczestnictwie w podkulturze (obie formy zwykle kontaminują);

c) zadomowienia - stanowiącej taktykę typową dla recydywistów, polegającej na stworzeniu sobie $\mathrm{w}$ więzieniu możliwości swobody działania i znośnych warunków egzystencji. Taki typ taktyki najczęściej obierają ska-

${ }^{21}$ R. Pawłowska, E. Jundziłł, Pedagogika człowieka samotnego, Gdańska 2006, s. 9.

22 S. Grzesiak, Egzystencjalny wymiar starości, s. 99.

${ }^{23}$ Tamże, s. 101.

${ }^{24}$ Por. E. Goffman, Charakterystyka instytucji totalnych, [w:] W. Derczyński, A. Jasińska-Kania, J. Szacki (wyb.), Elementy teorii socjologicznych: materiały do dziejów współczesnej socjologii zachodniej, Warszawa 1975, s. 150-176; także: M. Ciosek, Psychologia sądowa, s. 212-213. 
zani odporni psychicznie lub przyzwyczajeni do warunków więziennych, o przewadze orientacji poznawczej nad emocjonalną, często psychopaci;

d) konwersji - będącej postawą pozornej uległości wobec służb więziennych, wiążącej się z poszukiwaniem sytuacji jak najbardziej korzystnej dla siebie (porównywana do funkcji kapo w obozach koncentracyjnych);

e) zimnej kalkulacji - uosabiającej kombinację różnych sposobów adaptacji więziennej, głównie techniki zadomowienia i konwersji. Polega na wykorzystywaniu przez więźnia tajemnic, słabostek personelu oraz zwyczajów więźniów w celu uzyskania zakazanych oficjalnie gratyfikacji.

J. Sikora wskazuje na istnienie jeszcze innej techniki - tak zwanego mechanizmu hamowania procesu przeżywania sytuacji trudnej - polegającej na unikaniu myśli i rozmów o życiu na wolności, kształtowaniu postawy obojętności wobec życia poza więzieniem i spędzaniem czasu na wykonywaniu różnych zajęć.

Izolacja więzienna jest czynnikiem bezpośrednio wpływającym na powstawanie stanów nerwicowych, utrudniającym wychowawcze oddziaływanie na więźniów i zmniejszających siłę przystosowania skazanego do życia w środowisku otwartym ${ }^{25}$. Może ona również powodować nasilenie psychopatologicznych objawów występujących przed osadzeniem bądź powodować symptomy, które wcześniej nie występowały. Samookaleczenie niejednokrotnie stanowi przepustkę do awansu w hierarchii więziennej subkultury, co pozwala na wyegzekwowanie uprzednio nieosiągalnych żądań wśród osadzonych, jak i personelu. Jest również przejawem bezradności wobec deprecjacji godności, deprywacji podstawowych potrzeb, degradacji społecznej. Autoagresja może być również efektem stygmatyzacji przez grupę ${ }^{26}$.

Według L. Rabinowicza ${ }^{27}$, postępujący rozpad życia psychicznego przebiega w trzech etapach, jak:

1) przygnębienie, rozpacz, wstrząs po uwięzieniu;

2) smutek, nuda, egalizacja, tęsknota za ludźmi na wolności;

3) duchowe wyciszenie, bezwład, znieruchomienie, poddanie się nudzie i monotonii, cierpienie.

Zdaniem B. Waligóry i Z. Madeja ${ }^{28}$, pierwszy okres to rozpacz oraz przygnębienie, obniżenie nastroju, czasami załamanie psychiczne, a także ból izolacji. Z czasem pojawia się apatia, znieruchomienie psychofizyczne, zanik zainteresowania, lęk, zaburzenia gastryczne, ubytek wagi. U osób

\footnotetext{
25 A. Bałandynowicz, Probacja. Wychowanie do wolności, Warszawa 1995, s. 14-15.

26 Por. A. Bartczak-Praczkowska, M. Barwińska-Gojawiczyńska, Samouszkodzenia jako forma manifestowania rozpaczy, Biuletyn Okręgowej Izby Pielęgniarek i Położnych, 2004, 2, s. 13-21.

27 Cyt. za M. Ciosek, Człowiek w obliczu izolacji więziennej, Gdańsk 1996, s. 163.

28 Tamże, s. 163-164.
} 
o wyższym poziomie inteligencji po szoku wywołanym trafieniem do więzienia może wystąpić autorefleksja oraz poczucie winy, natomiast u osób silnie zintegrowanych ze środowiskiem przestępczym następuje dalsza deformacja postaw i systemu wartości, a także gniew oraz bunt. Po okresie depresyjnym następuje faza psychofizycznej aktywności, zmienności nastroju, wrażliwości, agresji i autoagresji, impulsywności, reakcji histeropodobnych i neurotycznych.

Widzimy więc, że zachowania wywołane stresem mogą być bardzo różne i jak zawsze w takich wypadkach zależne całkowicie od cech jednostkowych oraz doświadczeń życiowych osadzonego.

Przewlekłe sytuacje trudne prowadzą do rozmaitych zaburzeń o charakterze:

- psychologicznym, np. dekoncentracja uwagi, nadwrażliwość, zaburzenia snu;

- fizjologicznym, np. owrzodzenia przewodu pokarmowego, wzrost wydzielania adrenaliny, nadciśnienie tętnicze;

- behawioralnym, np. spadek lub wzrost wagi ciała, niezdolność poradzenia sobie z nowymi sytuacjami życiowymi ${ }^{29}$.

Jak zauważa A. Matysiak-Błaszczyk, nawet przy założeniu, że człowiek posiada spore predyspozycje adaptacyjne, to sytuacja izolacji i związane z nią sytuacje trudne są dużym, nie dającym się rozwiązać problemem:

(...) negatywne oddziaływania izolacji na psychikę człowieka powodują zakłócenia w sferze świadomości, uczuć, procesów podejmowania decyzji, co w konsekwencji prowadzi do zaburzeń w zachowaniu ${ }^{30}$.

Bierna postawa skazanych w wieku senioralnym wiąże się też z podejmowaniem wobec nich standardowych oddziaływań resocjalizacyjnych, które w praktyce sprowadzają się do działań formalnourzędowych, podczas gdy bardziej niż resocjalizacji seniorzy

wymagają podejścia pomocowo-socjalnego (opieki, pomocy, kompensacji) oraz szczególnego zainteresowania z uwagi na ich różnego rodzaju zdrowotne, edukacyjne, psychiczne i społeczne deficyty oraz potrzeby. Działania podejmowane wobec skazanych seniorów powinny mieć charakter opiekuńczo-leczniczy i readaptacyjny, uwzględniający treści z zakresu gerontologii resocjalizacyjnej. Ten obszar resocjalizacji jest nową przestrzenią eksploracji wobec wzrastającego udziału osób starzejących się i starych w jednostkach penitencjarnych ${ }^{31}$.

\footnotetext{
29 Tamże, s. 233.

30 A. Matysiak-Błaszczyk, Sytuacja życiowa kobiet pozbawionych wolności, Kraków 2010, s. 46.

31 J.A. Komeński, Pampaedia, s. 100.
} 


\section{Seniorzy w jednostkach penitencjarnych - założenia teoretyczne}

Dziedziną, która w sposób szczególny zajmuje się problemami seniorów znajdujących się w jednostkach penitencjarnych jest gearagogika resocjalizacyjna. Główny jej cel stanowi tworzenie warunków pomyślnego starzenia się, to jest starzenia się ze świadomością możliwości nieustannego rozwoju, a także możliwości uzyskania pomocy w rozwoju ze strony osób i instytucji. Podstawowym determinantem geragogiki resocjalizacyjnej winna być powszechność, rozumiana jako możliwość realizowania jej celów zarówno przez profesjonalnych, jak i nieprofesjonalnych wychowawców. Ponadto, należy wykorzystywać ją w instytucjach i organizacjach nastawionych na intencjonalną pracę wychowawczą z osobami starszymi (jak uniwersytety trzeciego wieku, kluby seniora, kursy przedemerytalne), a także z dziećmi, młodzieżą i dorosłymi (podczas zajęć, w których można realizować cele wychowania do starości). Aby była skuteczna, musi odbywać się w ramach funkcjonowania takich środowisk, jak rodzina, sąsiedztwo, parafie, zakład pracy, stowarzyszenie społeczne i tym podobne, a także być realizowana za pośrednictwem środków masowego przekazu².

Człowiek stary przebywający w zakładzie karnym ma w zasadzie takie same zadania rozwojowe, jak cała populacja osób w okresie późnej dorosłości. Organizacja odbywania kary pozbawienia wolności gwarantuje starszym ludziom zaspokojenie podstawowych potrzeb więźniów, to jest potrzeby wyżywienia czy ochrony zdrowia. Ich potrzeby nie różnią się przecież od tych, jakie przejawia człowiek na innych etapach życia. Niewątpliwie, do najsilniejszych potrzeb w okresie starości zaliczyć trzeba: potrzebę bezpieczeństwa emocjonalnego, przynależności, życzliwości, afirmacji siebie i świata, potrzebę uznania i bycia użytecznym (z tym że potrzeba bezpieczeństwa, przynależności i szacunku jest odczuwana znacznie silniej niż w poprzednich etapach życia) ${ }^{33}$.

Mówiąc o zadaniach geragogiki resocjalizacyjnej, należy wyjść właśnie od tych, które formułuje pedagogika starości w ogóle, skoro to na jej gruncie się ukształtowała. Do najważniejszych zaliczyć trzeba:

- uświadomienie skazanym w podeszłym wieku, jak przebiega proces starzenia się i starości (zrozumienie tego naturalnego procesu nie tylko pomaga w przygotowaniu więźniów do starości, ale pozwala też określić zadania, które stoją przed nimi w tym okresie) - czyli edukacja do starości;

32 A. Leszczyńska-Rejchert, Geragogika jako subdyscyplina pedagogiczna, s. 227-229.

33 A. Jaworska, Możliwości eliminowania starości patologicznej w zakładach karnych, [w:] Senior w obliczu izolacji penitencjarnej. Konteksty teoretyczne, red. A. Jaworska, Bydgoszcz 2013, s. 82. 
- dokładne zdiagnozowanie aktualnego stanu zdrowia (zarówno fizycznego, jak i psychicznego) więźniów w wieku senioralnym, w celu rozpoznania ich specyficznych, zmieniających się wraz z wiekiem potrzeb;

- dobranie odpowiednich metod i wskazanie środków, które umożliwią optymalną opiekę nad seniorami odbywającymi wyrok w zakładzie karnym oraz zapewnienie takich warunków pobytu w zakładzie, które dostosowane będą do ich stanu zdrowia fizycznego i psychicznego (w tym działań rehabilitacyjnych i terapeutycznych);

- edukowanie personelu więziennego w celu kształtowania prawidłowych postaw wobec więźniów w wieku senioralnym;

- socjalizację (zamiast resocjalizacji) skazanych $\mathrm{w}$ wieku senioralnym - wzmożenie działań zmierzających do odnalezienia własnego miejsca człowieka starego $\mathrm{w}$ rodzinie, nawiązanie kontaktu z bliskimi: dziećmi, współmałżonkiem, rodzeństwem (jeżeli kiedykolwiek ich posiadał) oraz doprowadzenie do odnowienia tych kontaktów i pojednania;

- systematyczne przygotowywanie człowieka starego do umierania i śmierci poprzez uświadamianie naturalności tego stanu - chodzi tu nie tylko o rozbudzenie refleksji nad kończącym się życiem czy próbę odnalezienia sensu kończącego się życia, ale głównie o dokonanie bilansu życia (z naciskiem na dostrzeżenie pozytywnych jego aspektów), wybaczenie (sobie i innym) i odnalezienie spokoju;

- aktywizowanie seniorów odbywających wyroki w zakresie optymalizowania jego sprawności umysłowej (pamięci, zdolności uczenia się, wyobraźni) i działalności twórczej ${ }^{34}$.

Zadanie to ściśle wiąże się ze współczesną tendencją pojawiającą się w badaniach naukowców, którzy dowodzą, że zdolności umysłowe osób $\mathrm{w}$ okresie senioralnym (tzw. inteligencja skrystalizowana, obejmująca m.in. doświadczenie życiowe, wiedzę, zakres słownictwa) nie ulegają obniżeniu wraz z wiekiem, mimo że z upływem lat obniża się szybkość i oryginalność myślenia. W związku z tym formy aktywizowania więźniów w wieku senioralnym muszą sprzyjać podtrzymaniu sprawności procesów intelektualnych, a edukacja i zajęcia kulturalno-oświatowe powinny w takim samym stopniu obejmować starych, co i młodych więźniów. Nie inaczej jest ze zdolnościami twórczymi seniorów, które utrzymują się do późnych lat starości; należałoby więc wykorzystać ten fakt w szerokiej działalności artystycznej, a w szczególności w dziedzinie plastyki i literatury. Ma to niebagatelne znaczenie dla autorefleksji oraz kształtowania bardziej pozytywnego bilansu życia - pozostawienia po sobie trwałego dorobku („,efekt ostatniej pracy",

${ }^{34}$ Za A. Zych, Człowiek wobec starości. Szkice o gerontologii społecznej, Katowice 1999, s. 22-24. 
„artystyczny testament”) $)^{35}$. Aktywność twórcza ponadto silnie wpływa na obniżenie lęku i przeciwdziałanie depresji, a także na budowanie większego poczucia sensu życia, co ma niebagatelne znaczenie w zapobieganiu patologicznej starości ${ }^{36}$.

Reasumując, podstawowym zadaniem, jakie stoi przed oddziaływaniami penitencjarnymi wobec ludzi starszych jest więc przede wszystkim wspomaganie ich rozwoju $\mathrm{w}$ okresie późnej dorosłości w warunkach pozbawienia wolności. Oddziaływania resocjalizacyjne powinny skupiać się na rozwoju duchowym, fizycznym, umysłowym, ale też społecznym i kulturalnym, a więc opierać się zasadniczo na działaniach o charakterze opiekuńczym, pomocowym, rehabilitacyjno-rewalidacyjnym i kompensacyjnym ${ }^{37}$.

Geragogika resocjalizacyjna to szereg oddziaływań mających na celu wspomaganie osób starszych odbywających karę pozbawienia wolności. Ich skuteczność uzależniona jest jednak od odpowiedniego wyszkolenia funkcjonariuszy służby więziennej. To właśnie personel więzienny musi mieć szeroką interdyscyplinarną wiedzę z dziedziny geragogiki i gerontologii, aby odpowiednio kierować oddziaływaniami penitencjarnymi wobec osadzonych seniorów.

Do pracy z seniorami brakuje specjalistycznych, dobrze wykształconych kadr, legitymujących się dyplomami wyższych uczelni. Zaledwie kilka uczelni w Polsce na kierunkach pedagogicznych uruchomiło specjalności związane z pracą na rzecz seniorów (np. edukacja zdrowotna i geragogika jako specjalność na pedagogice), kilka innych w programie studiów umieściło kursy z zakresu gerontologii społecznej. Kwestią czasu jest otwarcie samodzielnych kierunków studiów kształcących kadry dla instytucji działających na potrzeby starzejącego się społeczeństwa ${ }^{38}$.

\section{Seniorzy w jednostkach penitencjarnych - aspekty praktyczne}

Na podstawie moich badań mogę stwierdzić, że pomimo trudności przystosowawczych, przeżywania napięcia emocjonalnego, lęków, zaburzeń nerwicowych, łącznie z samoagresją i próbami samobójczymi, osadzeni w zdecydowanej większości potrafią zaadaptować się do warunków izolacji (adaptacja ta w wielu przypadkach jest po prostu wymuszona narzuconą sytuacją i brakiem jakiejkolwiek alternatywy). Przychodzi ona o wiele łatwiej

35 A. Jaworska, Możlizwości eliminowania starości patologicznej, s. 83.

${ }^{36}$ Zob. A. Jaworska, Aktywność twórcza więźniów a ich cechy osobowości i styl adaptacji do warunków więziennych, Słupsk 2007.

${ }^{37}$ A. Jaworska, Możliwości eliminowania starości patologicznej, s. 83-84.

${ }^{38}$ E. Piłat, Wychowanie do starości, http://www.dziennikpolski24.pl/artykul/1295328,wychowanie-do-starosci,id,t.html 
tym, którzy przebywają w więzieniu po raz kolejny (recydywiści), mają - jak sami to określają - wyrobiony status przestępcy, potrafią szybko ocenić zaistniałą sytuację, wejść w panujące w więzieniu układy, zaakceptować istniejącą hierarchię bądź też narzucić innym swój tok myślenia i podporządkować ich sobie. Niektórzy z badanych traktują zakład penitencjarny niemal jak swój drugi dom (albo też jedyny dom) i nie wyobrażają sobie innego życia, ponieważ wolność kojarzy im się z koniecznością podjęcia nisko płatnej i niezbyt atrakcyjnej pracy (o ile w ogóle ją otrzymają, a ich szanse będą ograniczone ze względu na przestępczą przeszłość), opłacania mieszkania, walką o byt. Przystosowanie do warunków izolacji więziennej o wiele trudniej jednak przychodzi osobom w wieku starszym. Wydawać by się mogło, że problem dotyczy niewielkiej grupy osadzonych, ale jak wynika z raportu CZSW, wśród osadzonych jest dość spora liczba osób starszych.

Tablica $1^{39}$

Zestawienie wiekowe więźniów seniorów w Polsce

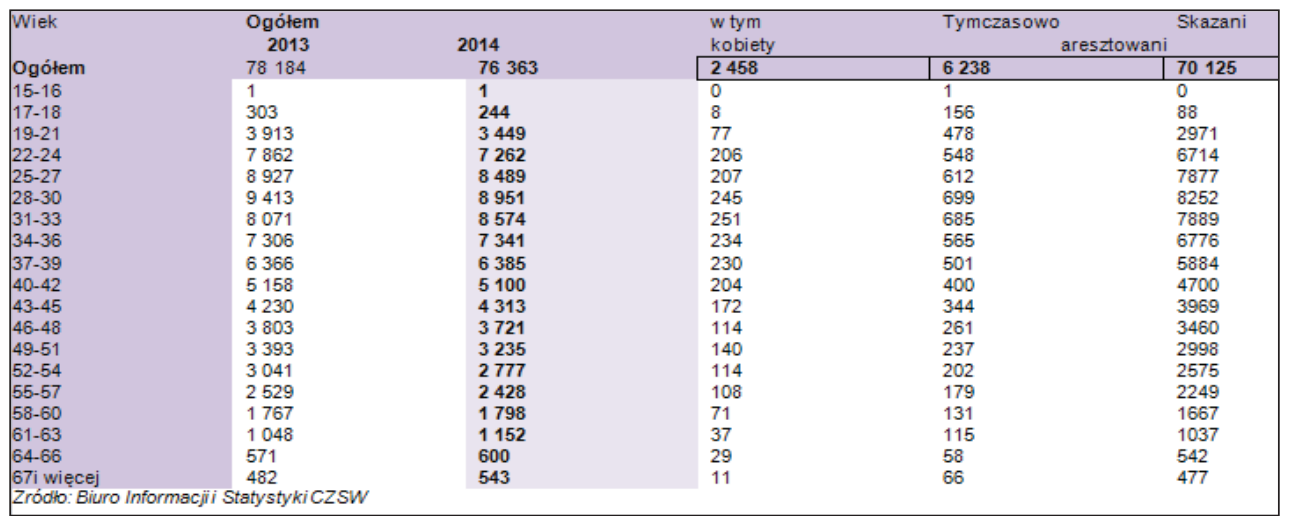

Więźniów seniorów można podzielić na trzy podstawowe grupy:

1) osoby umieszczone $w$ zakładach karnych na wieloletnie lub dożywotnie wyroki kiedy jeszcze były młode (co oznacza, że większą część życia spędzili w więzieniu, bez nawet krótkotrwałych pobytów na wolności);

2) wielokrotnych recydywistów, których wielokrotne pobyty w więzieniu przeplatały się z krótkimi okresami wolności stanowiącymi dla nich okazję do popełniania kolejnych przestępstw;

3) więźniów po raz pierwszy uwięzionych w wieku senioralnym (statystyki wskazują, że ich zbrodnie są znacznie poważniejsze, aniżeli te, których dopuszczają się osoby młodsze, często też otrzymują dłuższe od nich wyroki $)^{40}$.

39 Według Biura Informacji Statystyki CZSW.

${ }^{40}$ Za A. Jaworska, Starość patologiczna w zaktadach karnych, [w:] Senior w obliczu izolacji penitencjarnej. Konteksty teoretyczne, red. A. Jaworska, Bydgoszcz 2013, s. 69. 
Osadzeni w wieku senioralnym (więźniowie geriatryczni) stanowią jedną z wielu grup więźniów o specjalnych potrzebach (obok osób niepełnosprawnych fizycznie - z upośledzonym organem wzroku, słuchu i ruchu, więźniów niepełnosprawnych intelektualnie oraz chorych psychicznie, przewlekle chorych, uzależnionych od substancji psychotropowych oraz zakażonych wirusem HIV i chorych na AIDS). Nic więc dziwnego, że jako jedna z tych grup generują większe niż ogólna populacja skazanych zapotrzebowanie na profesjonalny personel medyczny (wykwalifikowane pielęgniarki i lekarzy), zwiększony zakres terapii medycznych, doradców psychologicznych, modernizację bazy strukturalnej zakładów karnych oraz rozbudowanie i unowocześnienie ich bazy medycznej ${ }^{41}$.

Z raportu opartego na wywiadach z ponad setką starszych osób odbywających kary więzienia wynika, że starsi wiekiem więźniowie żyją w izolacji i dyskryminacji, ponieważ państwo nie jest w stanie zapewnić im specjalistycznej opieki medycznej i socjalnej oraz prowadzić właściwej działalności resocjalizacyjnej. Więźniowie poruszający się na wózkach inwalidzkich nie są w stanie brać udziału w codziennych zajęciach.

Doktor Zofia Szarota - profesor Uniwersytetu Pedagogicznego w Krakowie i Dziekan Wydziału Pedagogicznego tłumaczy: „Największy problem w tym, że geragogów nie ma w oficjalnym spisie zawodów. Są tylko wykładowcy oświaty dla dorosłych i edukatorzy, a to nie to samo" ${ }^{2}$. Przed uczelniami stoi więc poważne wyzwanie, aby w obliczu starzejącego się coraz bardziej społeczeństwa podjąć wyzwanie i tworzyć nie tylko kierunek geragogika jako specjalność na pedagogice czy w programie studiów przewidywać kursy z zakresu gerontologii społecznej, ale także szkolić studentów resocjalizacji do pracy z seniorami osadzonymi w zakładach karnych. A jest ich w Polsce niemało.

Skazanych zaawansowanych wiekiem bez trudu odnalazłam w oddziale szpitalnym dla przewlekle chorych Zakładu Karnego w Czarnem. W jednej z cel pytam seniorów o lata. - Siedzę tu już osiem. - Ja cztery. - A ja dwa - odpowiadają jeden po drugim. Ale metrykalnie, według kryteriów WHO, już zaliczają się do staruszków. - To jedyny taki oddział w Polsce - mówi por. Ewa Bartkowska, kierownik działu penitencjarnego. - Przebywają w nim więźniowie z chorobami wewnętrznymi, neurologicznymi, chirurgicznymi, a także więźniowie niepełnosprawni. Trafiają tu z całego kraju. Na miejsce muszą czekać co najmniej dwa lata - dodaje kpt. Beata Krzyżanowska, p.o. kierownika działu terapeutycznego dla skazanych z zaburzeniami niepsychotycznymi i upośledzonych umysłowo ${ }^{43}$.

\footnotetext{
41 Tamże, s. 70 .

42 Tamże.

43 Uwięziona starość - Forum Penitencjarne nr 04(191), kwiecień 2014, s. 7.
} 


\section{Wyzwania dla geragogiki penitencjarnej}

Aby starzenie mogło odbywać się w sposób korzystny, trzeba pamiętać o zaspokajaniu potrzeb seniorów. A.H. Maslow zwracał uwagę na sześć zasadniczych grup takich potrzeb: fizyczne, dotyczące bezpieczeństwa, przynależności i miłości, szacunku, samorealizacji oraz estetyczne. Takie wielokierunkowe działania są niezwykle skomplikowane i wymagają dużego zaangażowania osoby zainteresowanej oraz jej otoczenia. Spełnienie tych potrzeb w izolacji penitencjarnej rzadko kiedy może być w pełni zrealizowane ${ }^{44}$.

Istotną kwestią związaną ze starością w izolacji penitencjarnej jest także zagadnienie godności. $Z$ całą pewnością nie może ona być stanem tymczasowym związanym z etapem życia jednostki. Powinna natomiast opierać się na ontologicznym przekonaniu o wartości, jaką jest człowieczeństwo ${ }^{45}$. Właśnie dlatego kształcenie osób, które pracują z osobami starymi w zakładach karnych musi zawierać zagadnienia związane z możliwościami kształtowania i rozwijania poczucia godności seniorów wychodzące poza utarte schematy. Nie sposób bowiem mówić o godności osoby, która pozostaje zależna od innych, jeśli nie uwzględni się $\mathrm{w}$ pracy $\mathrm{z}$ nią indywidualnego podejścia i zrozumienia procesu starzenia się i starości.

Literatura przedmiotu wskazuje szereg kluczowych zagadnień związanych z poczuciem godności seniorów przebywających w zakładach karnych. Należą do nich przede wszystkim:

- zapewnianie indywidualnej opieki i wsparcia,

- poszanowanie indywidualnych wartości i przyzwyczajeń,

- dostosowywanie opieki do potrzeb i rytmu jednostki,

- szanowanie granic indywidualnych ograniczeń,

- wspieranie osób starszych w utrzymywaniu higieny i wyglądu,

- zapewnianie komfortu i uwagi,

- przewidywanie indywidualnych potrzeb,

- utwierdzane w poczuciu własnej wartości,

- niestawianie ludzi starych w sytuacjach mogących doprowadzić do ich porażki w grupie,

- dodawanie odwagi do uczestnictwa w codziennym życiu,

- promowanie osobistego wyglądu i autoprezentacji ludzi starych odpowiednio do ich potrzeb i poczucia własnej wartości,

${ }^{44}$ A. Witiuk-Misztalska, T. Misztalski, Pozagenetyczne czynniki ksztattujące proces korzystnego starzenia - spojrzenie geriatry, [w:] Edukacja wobec starości - tradycja i wspótczesność, red. A. Stopińska-Pająk, Chowanna, 2009, 52(65), 2014, 2(33), s. 250.

${ }^{45} \mathrm{Za}$ Ż. Freund, D. Michniewicz, Prawo do godnej starości a zakład karny, [w:] Senior w obliczu izolacji, s. 115. 
- podwyższanie zdolności ludzi starych do przeciwstawiania się środowiskowym i organizacyjnym czynnikom naruszającym ich godność,

- tworzenie i podtrzymanie więzi społecznych, zapobiegających marginalizacji, izolacji społecznej i wykluczaniu ${ }^{46}$.

Tymczasem jednak, uwzględnianie warunków psychofizycznych seniorów przebywających w więzieniach wciąż należy do rzadkości. Powoduje to nie tylko sprowadzanie tej grupy ludzi starych na margines społeczeństwa, ale też na margines oddziaływań penitencjarnych, powodując również ich automarginalizację.

Proces starzenia może się wiązać ze spadkiem aktywności przestępczej, ale nie powinien oznaczać końca wszelkiej aktywności. Odpowiedni i efektywny dobór metod oddziaływań resocjalizacyjnych powinien przekonać do tego starszych skazanych. Może to być dobry moment na zmianę postaw seniorów na takie, jakie byłyby zgodne z obowiązującymi standardami społecznymi. Dokonanie bilansu życiowego jest niezbędne do przegrania lub wygrania starości. Pozytywny bilans życia jest to poczucie zadowolenia z niego, zrealizowania celów, marzeń i planów, satysfakcji z życia prywatnego, z rodziny, zadowolenia z pracy zawodowej, poczucie użyteczności, miłości, bezpieczeństwa, pogodzenie się z porażkami i problemami. W negatywnym bilansie życia dominują uczucia przeciwne, rozgoryczenie, niezadowolenie, smutek ${ }^{47}$.

Wynik bilansu życiowego wpływa na przygotowanie jednostki do procesu adaptacji do starości, procesu readaptacji społecznej eks-przestępcy oraz pogodzenia się z losem ${ }^{48}$.

Człowiek stary w więzieniu powinien być poddawany przede wszystkim oddziaływaniom wspomagającym. Należy budzić u niego refleksję; starość jest naturalnym i nieuniknionym etapem życia, ale nie powinien go traktować jako końca, a wręcz przeciwnie - jako drogę ku życiu ${ }^{49}$. Seniorom trzeba uświadamiać, że starość jest dobrym czasem na zdobywanie wiedzy, umiejętności oraz kształtowanie nawyków, postaw i zachowań - doskonalenie się i bogacenie swojej osobowości.

Dostępność tych obszarów dla seniorów w jednostkach penitencjarnych jest ograniczona, a i same postawy, style życia ludzi starych nie ułatwiają pracy penitencjarnej. Dlatego rozwój gerontologii resocjalizacyjnej jako adekwatnego do warunków psychofizycznych seniorów oddziaływania penitencjarnego wydaje się uzasadniony ${ }^{50}$.

46 Tamże, s. 114.

47 A. Tokaj, U progu starości, s. 39-40.

48 S. Grzesiak, Człowiek starszy w placówce penitencjarnej, [w:] Resocjalizacja. Zagadnienia prawne, społeczne i metodyczne, red. A. Jaworska, Kraków 2009, s. 255.

${ }^{49}$ W. Tłokiński, Stowo wstępne, [w:] Wypetnianie starości - trening ku życiu, red. M. Krawczyński, Gdańsk 1997, s. 7-10.

50 S. Grzesiak, Człowiek starszy w placówce penitencjarnej, s. 255. 
Wydaje się tym bardziej uzasadnione, że większość osadzonych traktuje więzienie jak swój dom, w którym chce dożyć starości. Spirizonizowani osadzeni są bierni, popadają w marazm, nie podejmują prób zmiany swojej sytuacji, oczekują jedynie spokojnego życia. W ich oczach więzienie jest najlepszym z możliwych miejsc na dożycie starości. Przed geragogiką resocjalizacyjną stoi zatem współcześnie szereg wyzwań, aby długowieczność i starość tych ludzi spełniała się w warunkach wolnościowych, a nie więziennych.

\section{BIBLIOGRAFIA}

Bałandynowicz A., Probacja. Wychowanie do wolności, Warszawa 1995.

Bartczak-Praczkowska A., Barwińska-Gojawiczyńska M., Samouszkodzenia jako forma manifestowania rozpaczy, Biuletyn Okręgowej Izby Pielęgniarek i Położnych, 2004, 2.

Ciosek M., Człowiek w obliczu izolacji więziennej, Gdańsk 1996.

Ciosek M., Psychologia sądowa i penitencjarna, wyd. II, Warszawa 2003.

Czerniawska O., Starość wczoraj, dziś i jutro, [w:] Ludzie starsi w trzecim tysiącleciu. Szanse nadzieje - potrzeby, red. W. Wnuk, Wrocław 2002.

Freund Ż., Michniewicz D., Prawo do godnej starości a zakład karny, [w:] Senior w obliczu izolacji penitencjarnej. Konteksty teoretyczne, red. A. Jaworska, Bydgoszcz 2013.

Goffman E., Charakterystyka instytucji totalnych, [w:] W. Derczyński, A. Jasińska-Kania, J. Szacki (wyb.), Elementy teorii socjologicznych: materiaty do dziejów wspótczesnej socjologii zachodniej, Warszawa 1975.

Grzesiak S., Człowiek starszy w placówce penitencjarnej, [w:] Resocjalizacja. Zagadnienia prawne, społeczne i metodyczne, red. A. Jaworska, Kraków 2009.

Grzesiak S., Egzystencjalny wymiar starości w zakładzie karnym - doświadczanie czasu i samotności przez więźniów seniorów, [w:] Senior w obliczu izolacji penitencjarnej. Konteksty teoretyczne, red. A. Jaworska, Bydgoszcz 2013.

Halicki J., Edukacja osób starszych w Polsce - jej wymiar teoretyczny i praktyczny. Studia nad kondycją edukacji dorostych, Edukacja Dorosłych 2013, 2.

Jaworska A., Aktywność twórcza więźniów a ich cechy osobowości i styl adaptacji do warunków więziennych, Słupsk 2007.

Jaworska A., Możliwości eliminowania starości patologicznej w zakładach karnych, [w:] Senior w obliczu izolacji penitencjarnej. Konteksty teoretyczne, red. A. Jaworska, Bydgoszcz 2013.

Jaworska A., Starość patologiczna w zakładach karnych, [w:] Senior w obliczu izolacji penitencjarnej. Konteksty teoretyczne, red. A. Jaworska, Bydgoszcz 2013.

Komeński J.A., Pampaedia, Wrocław 1973.

Kowalczyk A., Specyfika problemów osób starszych w zakładzie karnym, [w:] Senior w obliczu izolacji penitencjarnej. Konteksty teoretyczne, red. A. Jaworska, Bydgoszcz 2013.

Leszczyńska-Rejchert A., Człowiek starszy i jego wspomaganie - w strone pedagogiki starości, Olsztyn 2010.

Leszczyńska-Rejchert A., Geragogika jako subdyscyplina pedagogiczna - założenia i formy realizacji, [w:] Edukacja wobec starości - tradycja i wspótczesność, red. A. Stopińska-Pająk, Chowanna, 2009, 52(65), 2014, 2(33).

Matysiak-Błaszczyk A., Sytuacja życiowa kobiet pozbawionych wolności, Kraków 2010.

Nawój J., Świat przemocy w więzieniu, [w:] Przemoc w więzieniu, red. J. Nawój, Kule 1998. 
Nowicka A., Starość jako faza życia człowieka, [w:] Wybrane problemy osób starszych, red. A. Nowicka, Kraków 2008.

Olszewski H., Starość i starzenie się [w:] Encyklopedia psychologii, red. W. Szewczuk, Warszawa 1998.

Orzechowska A.(red.), Samouszkodzenia wśród więźniów a czynniki psychospołeczne, [w:] Suicydologia, t. 4, nr 1, Warszawa 2008.

Pawłowska R., Jundziłł E., Pedagogika człowieka samotnego, Gdańsk 2006.

PiłatE.,Wychowaniedostarości,[Internet:http:/ / www.dziennikpolski24.pl/artykul/1295328, wychowanie-do-starosci,id,t.html] [dostęp: 20.04.2016].

Szczepaniak P., Kara pozbawienia wolności a wychowanie, Kalisz - Warszawa 2003.

Tłokiński W., Stowo wstępne, [w:] Wypetnianie starości - trening ku życiu, red. M. Krawczyński, Gdańsk 1997.

Tokaj A., U progu starości (studium socjopedagogiczne), Poznań 2000.

Uglorz M., Geragogika, http://mku.blox.pl/resource/Geragogika.pdf

Uwięziona starość - Forum Penitencjarne nr 04(191), kwiecień 2014.

Waligóra B., Deprywacja potrzeb u osób pozbawionych wolności, [w:] Problemy wspótczesnej penitencjarystyki w Polsce, t. 1, red. B. Hołyst, Warszawa 1984.

Witiuk-Misztalska A., Misztalski T., Pozagenetyczne czynniki kształtujace proces korzystnego starzenia - spojrzenie geriatry, [w:] Edukacja wobec starości - tradycja i wspótczesność, red. A. Stopińska-Pająk, Chowanna, 2009, 52(65), 2014, 2(33).

Zych A., Człowiek wobec starości. Szkice o gerontologii społecznej, Katowice 1999.

Zych A., Stownik gerontologii społecznej, Warszawa 2001. 